J. Vet. Med. A 49, 93-98 (2002)

(C) 2002 Blackwell Wissenschafts-Verlag, Berlin

ISSN 0931-184X

Servicio de Ecopatología de Fauna Silvestre, Facultad de Veterinaria, Universidad Autónoma de Barcelona, Bellaterra, Barcelona, Spain

\title{
Delayed Acute Capture Myopathy in Three Roe Deer
}

\author{
J. Montané, I. Marco, X. Manteca, J. López and S. Lavín ${ }^{1}$
}

Address of authors: Servicio de Ecopatología de Fauna Silvestre, Facultad de Veterinaria, Universidad Autónoma de Barcelona, 08193 Bellaterra, Barcelona, Spain; ${ }^{1}$ Corresponding author: E-mail: Santiago.Lavin@uab.es

With 4 figures and 2 tables

Received for publication February 28, 2001

\section{Summary}

Delayed acute capture myopathy is the term used to describe the clinical syndrome observed in three roe deer captured by drive-nets and transported to an enclosure for scientific purposes. The animals died $48 \mathrm{~h}, 60 \mathrm{~h}$ and 8 days after being captured. The simultaneous deaths coincided with a previous episode of deliberate human disturbance. The histopathological findings were indicative of acute myopathy and myoglobinaemic nephrosis. These could be related to an ataxic myoglobinuric syndrome brought on by capture and transport operations. The lack of clinical signs and negative prognosis indicators in the period between capture and just before death, the absence of gross muscular lesions in the animal that died after 8 days post-capture, the simultaneous deaths of animals captured at different times and the evidence of deliberate human disturbance in the enclosure are suggestive of death triggered by a second stress episode.

\section{Introduction}

Capture myopathy is a syndrome that occurs in wild (freeranging and captive) mammals and birds. It is associated with the stress of capture, restraint and transportation. In ungulates the syndrome is characterized clinically by depression, muscular stiffness, lack of coordination, paralysis, metabolic acidosis and death. Pathologically, capture myopathy resembles the myodegenerative disorders of domestic cattle, sheep, horse and swine (Chalmers and Barrett, 1982).

The classification of capture myopathy into peracute, acute, subacute and chronic is somewhat arbitrary and different authors have adopted different classification systems (Harthoorn, 1976; Chalmers and Barrett, 1982; Shepherd, 1984). Spraker (1993) described four clinical syndromes in animals: capture shock, ataxic myoglobinuric, ruptured muscle and delayed peracute syndrome. The ataxic myoglobinuric syndrome probably occurs most commonly. It can be seen several hours to several days post-capture. Clinical signs include ataxia, torticollis and myoglobinuria, and vary from mild to severe. At necropsy there are renal and skeletal muscle lesions. The kidneys are swollen and dark. The urinary bladder is empty or contains a small amount of brownish urine. Multifocal, pale, soft, dry areas, accentuated by small white foci in a linear pattern are usually found within the cervical and lumbar muscles and in the flexor and extensor muscles of the limbs. These lesions are subtle in animals that die 1-2 days postcapture but pronounced in animals that survive longer. The delayed peracute syndrome is usually seen in animals that have been in captivity for at least $24 \mathrm{~h}$. These animals appear normal while undisturbed, but if recaptured or suddenly stressed they die within several minutes. The syndrome pathogenesis is the consequence of a surge of epinephrine, which acts on altered membranes (due to hyperkalaemia) of heart and skeletal muscle cells, resulting in ventricular fibrillation. Usually, there are no lesions or only a few pale foci are found within the skeletal muscle at necropsy. Histological lesions are characterized by a mild to moderate rhabdomyolysis throughout the skeletal muscle, especially in the hind limbs.

Capture myopathy is a well-known pathological condition in wild ungulates, but only a Letter to the Editor (Fairlie, 1964) has been published in relation to a myopathy suggestive of capture myopathy in a roe deer.

\section{Materials and Methods}

In March 2000, three free-ranging female roe deer were captured by means of drive-nets in the National Game Reserve of Alt Pallars Aran $\left(47^{\circ} 22^{\prime} \mathrm{N} 3^{\circ} 48^{\prime} \mathrm{E}\right.$, northeastern Spain), translocated into transport boxes and then placed in captivity for scientific purposes. Drive-trapping was conducted by a line of beaters, each one within sight of the next, and went on for $30 \mathrm{~min}$. The animals were initially restrained using the net to wrap them in, blindfolded, their legs restrained and finally introduced into a transport sack net (Ziboni Ornitecnica, Bergamo, Italy), where they were maintained for approximately $1 \mathrm{~h}$ before being introduced into the transport boxes. The enclosure where the animals were kept in captivity was located in the Cadí-Moixeró Natural Park $\left(42^{\circ} 20^{\prime} \mathrm{N} 1^{\circ} 50^{\prime} \mathrm{E}\right.$, northeastern Spain) with an area of $1500 \mathrm{~m}^{2}$ and a forest zone. The behaviour of the animals was monitored every day at dawn and dusk for 2-h periods during captivity. No clinical signs of capture myopathy or abnormal behaviour were observed during the captivity period before death. The animals died $48 \mathrm{~h}$ (animal no. 1), $72 \mathrm{~h}$ (animal no. 2) and 8 days (animal no. 3) after being captured. Evidence of deliberate human disturbance was found in the enclosure, indicative of a second stress episode. It probably consisted of an intense pursuit inside the enclosure and the capture of one animal that disappeared and thus is not included in this report (initially there were four animals in the enclosure). The time to death from this disturbance was probably 15,41 and $21 \mathrm{~h}$, respectively.

Two blood samples had been taken $6 \mathrm{~h}$ (two animals) and $9 \mathrm{~h}$ (one animal) apart, at capture and after a 3-h road journey, as part of a research study. The blood was collected from the jugular vein and placed in a tube with EDTA $\mathrm{K}_{3}$ as an 
anticoagulant and used for haematological analyses. The remainder was placed in a plain tube and used for biochemical purposes, after being allowed to clot at room temperature. Serum was kept at $-18^{\circ} \mathrm{C}$ until biochemical analyses were carried out. Haematological examinations were performed by means of a semiautomatic analyser (Sysmex F-800, Toa Medical Electronics, Japan). Biochemical analyses were performed by means of an automated analyser (COVAS MIRA, Roche, Nutley, NJ, USA), except sodium and potassium concentrations which were measured by flame photometry (Corning 410C, Corning Medical, Medfield, USA). Statistical analyses were performed using a statistics software package (SPSS-PC ${ }^{\circledR}$, SPSS Inc., Chicago, IL, USA). A Wilcoxon test was used to compare haematological and biochemical values at capture and after transport.

Body temperature was recorded every minute after capture and during transportation using Mätman Datalogger ${ }^{\circledR}$ temperature probes (Chipsobits Eltex AB, Sweden). Heart rate was continuously recorded using Polar Vantage $\mathrm{NV}^{\circledR}$ noninvasive heart rate monitors (Polar Electro Oy, Finland). These measurements were also taken as part of the research study.

A necropsy of the roe deer was performed. Samples were taken from the heart, kidneys and skeletal muscles and were fixed in $10 \%$ buffered formalin for routine histopathological studies.

\section{Results}

\section{Clinical and clinicopathological findings}

No clinical signs of capture myopathy or abnormal behaviour were observed during the captivity period before death. Clinical signs just before death included depression, inability to rise or stand and unresponsiveness to human presence.

Haematological (Table 1) and biochemical (Table 2) data did not show any statistical difference at capture and after transport. Haematological values (except for elevated eosinophils), serum glucose, cholesterol and sodium were within the reference values reported by Jaouen (1981) for female roe deer captured by drive-nets. Serum urea was almost 2 -fold that reported by Jaouen (1981) $(6.97 \pm 1.22 \mathrm{mmol} / \mathrm{l})$ and the concentration of potassium was also higher than that reported by the same author $(5.27 \pm 0.81 \mathrm{mmol} / \mathrm{l})$.

Heart rate and body temperature after capture and during transportation of two of the animals are shown in Figs 1 and 2 , respectively. The heart rate decreased to the normal physiological values $(70-80$ beats $/ \mathrm{min})$ reported by Nielsen (1999) for deer, in $3 \mathrm{~h}$ (animal no. 1) and less than $30 \mathrm{~min}$ (animal no. 2). Schober and Wagner (1993) reported heart rate values obtained by telemetry of below 90 beats/min in roe deer not submitted to exertion. Rectal temperature reached the normal physiological value $\left(38.4^{\circ} \mathrm{C}\right)$ (Nielsen, 1999) after 1 and $3 \mathrm{~h}$, respectively.

\section{Gross pathological findings}

The roe deer were in good condition. Small superficial lacerations were found in the skin of their faces, on the upper ciliar arc, due to them pressing their heads hard against the enclosure fence as an attempt to escape when disturbed. One animal presented a transverse fracture affecting the last four ribs of the right side and subsequent subcutaneous emphysema (animal no. 1).

No macroscopic lesions were observed in myocardium and skeletal muscles, except for one animal that had a pale area over the serratus dorsalis and the latissimus dorsi (animal no. 2). The kidneys were dark and swollen in all animals. The bladder of two animals (nos 1 and 2) contained dark brown, turbid urine suggestive of myoglobinuria, while animal no. 3 only had a little amount of urine in the bladder and its colour was normal. Animal no. 1 also presented greyish noduli of semisolid consistency in the caudal lobes of both lungs.

\section{Histopathological findings}

The muscles that appeared grossly normal showed microscopic evidence of mild (animal no. 3) to severe (two animals, those with myoglobinuria) degeneration and fragmentation of skeletal muscle fibres (Fig. 3). There were fibres with central nuclei, marked exudation of eosinophilic material, probably proteinaceous, into the interstitial space, and the presence of some macrophages and polymorphonuclear neutrophils between the degenerated muscular fibres. All three animals also presented parasitic cysts in some muscular fibres compatible

Table 1. Haematological values of the three animals at capture and after transport. No statistical differences were found between samples obtained at capture and after transport

\begin{tabular}{|c|c|c|c|c|c|c|c|c|}
\hline & \multicolumn{4}{|c|}{ At capture } & \multicolumn{4}{|c|}{ After transport } \\
\hline & 1 & 2 & 3 & Mean $( \pm$ SEM $)$ & 1 & 2 & 3 & Mean $( \pm$ SEM $)$ \\
\hline $\mathrm{RBC}\left(\times 10^{12} / \mathrm{l}\right)$ & 10.19 & 9.13 & 11.16 & $10.16( \pm 0.59)$ & 8.45 & 12.75 & 9.72 & $10.31( \pm 1.28)$ \\
\hline Haemoglobin $(\mathrm{g} / \mathrm{l})$ & 145 & 196 & 164 & $168.3( \pm 14.9)$ & 140 & 184 & 140 & $154.7( \pm 14.7)$ \\
\hline PCV $(1 / 1)$ & 0.41 & 0.57 & 0.48 & $0.47( \pm 0.05)$ & 0.41 & 0.53 & 0.40 & $0.45( \pm 0.42)$ \\
\hline MCV (fl) & 40.2 & 62.4 & 41.4 & $48.00( \pm 7.21)$ & 48.5 & 41.6 & 41.1 & $43.73( \pm 2.39)$ \\
\hline $\operatorname{MCHC}(\mathrm{g} / \mathrm{dl})$ & 35.4 & 34.4 & 34.2 & $34.67( \pm 0.37)$ & 34.2 & 34.7 & 35.0 & $34.63( \pm 0.23)$ \\
\hline $\mathrm{MCH}(\mathrm{pg})$ & 14.2 & 21.5 & 14.7 & $16.80( \pm 2.35)$ & 16.6 & 14.4 & 14.4 & $15.13( \pm 0.73)$ \\
\hline WBC $\left(\times 10^{9} / 1\right)$ & 3.2 & 4.0 & 2.3 & $3.17( \pm 0.49)$ & 5.0 & 9.4 & 6.0 & $6.8( \pm 1.33)$ \\
\hline Lymphocytes $\left(\times 10^{9} / 1\right)$ & 1.504 & 1.680 & 1.150 & $1.44( \pm 0.16)$ & 1.100 & 0.188 & 0.480 & $0.59( \pm 0.27)$ \\
\hline Neutrophils $\left(\times 10^{9} / 1\right)$ & 1.344 & 1.800 & 0.828 & $1.32( \pm 0.28)$ & 3.800 & 9.024 & 5.340 & $6.05( \pm 1.55)$ \\
\hline Monocytes $\left(\times 10^{9} / 1\right)$ & 0.032 & 0.000 & 0.023 & $0.018( \pm 0.009)$ & 0.100 & 0.000 & 0.120 & $0.073( \pm 0.037)$ \\
\hline Eosinophils $\left(\times 10^{9} / 1\right)$ & 0.320 & 0.520 & 0.299 & $0.38( \pm 0.07)$ & 3.800 & 0.188 & 0.060 & $1.35( \pm 1.22)$ \\
\hline Basophils $\left(\times 10^{9} / 1\right)$ & 0 & 0 & 0 & $0( \pm 0)$ & 0 & 0 & 0 & $0( \pm 0)$ \\
\hline
\end{tabular}

SEM, standard error of the mean; RBC, red blood cells; PCV, packed cell volume; MCV, mean cell volume; MCHC, mean cell haemoglobin concentration; $\mathrm{MCH}$, mean cell haemoglobin; WBC, white blood cells. 


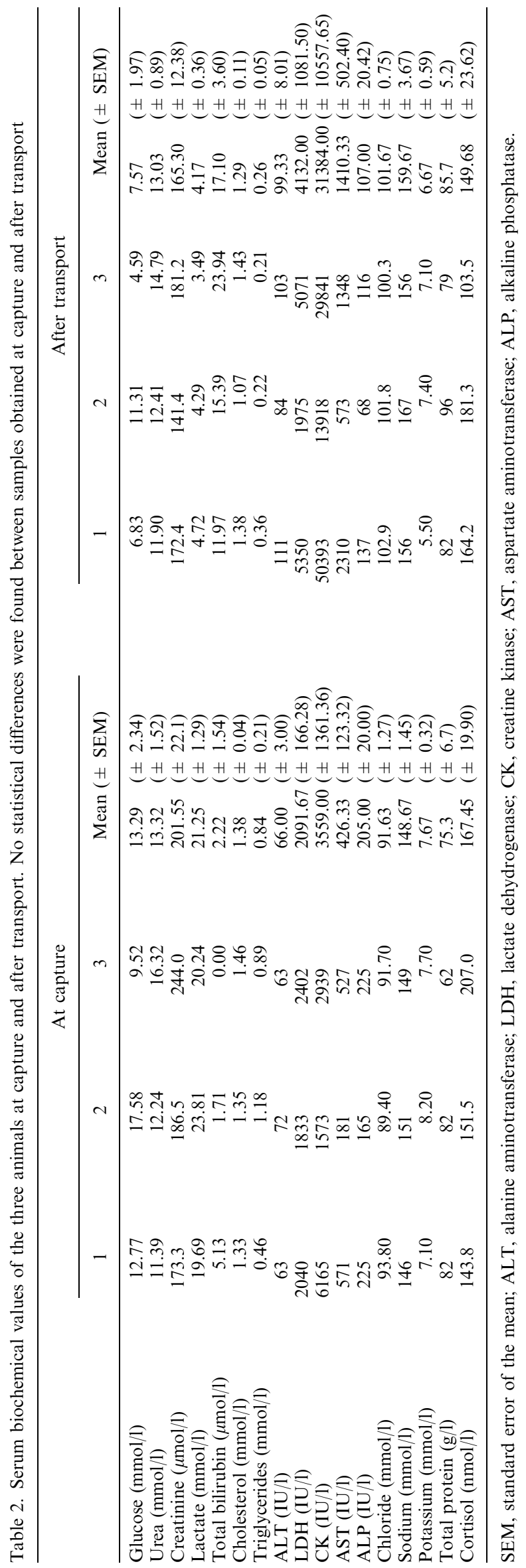

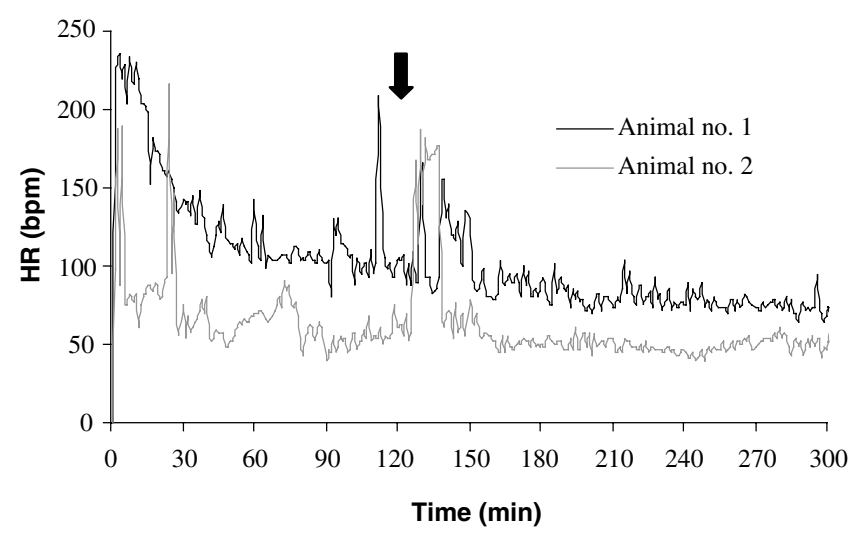

Fig. 1. Heart rate (beats/min) after capture and during transport of two of the animals. The mean heart rates were $103.70 \pm 2.09$ beats min (range $66-235$ beats $/ \mathrm{min}$ ) and $62.76 \pm 1.62$ beats/min (range 36 216 beats $/ \mathrm{min}$ ). The arrow indicates the beginning of the road journey.

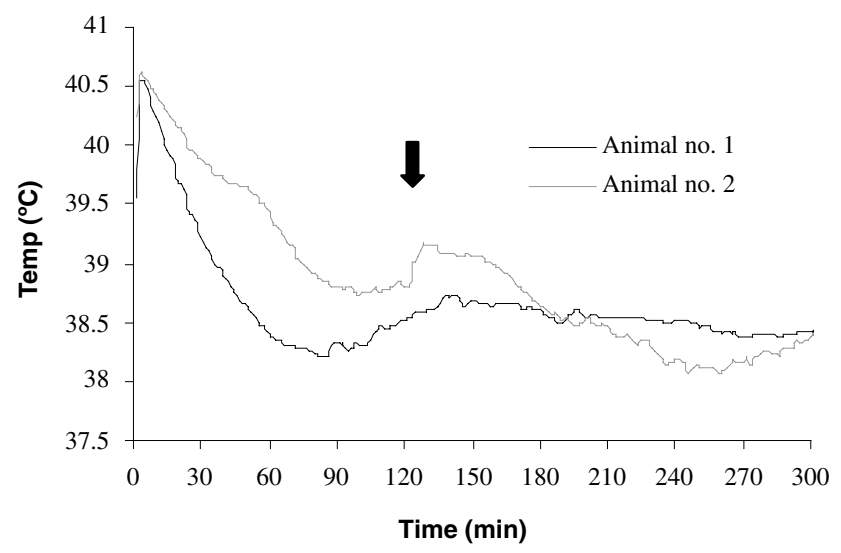

Fig. 2. Body temperature $\left({ }^{\circ} \mathrm{C}\right)$ after capture and during transport of two of the animals. The mean body temperatures were $38.65 \pm 0.03^{\circ} \mathrm{C}$ (range $38.2-40.55^{\circ} \mathrm{C}$ ) and $38.90 \pm 0.04^{\circ} \mathrm{C}$ (range $38.06-40.6^{\circ} \mathrm{C}$ ). The arrow indicates the beginning of the road journey.

with parasites of the genus Sarcocystis. Those animals with myoglobinuria had myocardic fibres that showed hyalinization and pycnotic nuclei multifocally.

In the kidneys of all three animals, some tubular cells in the cortex contained different amounts of a yellow-brown intracytoplasmic pigment (Fig. 4). Multifocal renal tubular necrosis in the cortex and the presence of degenerated tubular cells in the medulla and the cortex were observed.

Animal no. 1 presented large amounts of parasitic structures in pulmonary alveoli and bronchioli associated with fibrosis of septa and large amounts of macrophages, lymphocytes and some multinucleated giant cells. A diagnosis of chronic parasitic interstitial pneumonia was made.

\section{Discussion}

Meneguz et al. (1996) reported hyperthermia $\left(>41^{\circ} \mathrm{C}\right)$, tachycardia ( $>200$ beats $/ \mathrm{min})$, hypoglycaemia $(<3.64$ $\mathrm{mmol} / \mathrm{l}$ ), persistent relative polycythaemia (red blood cells 

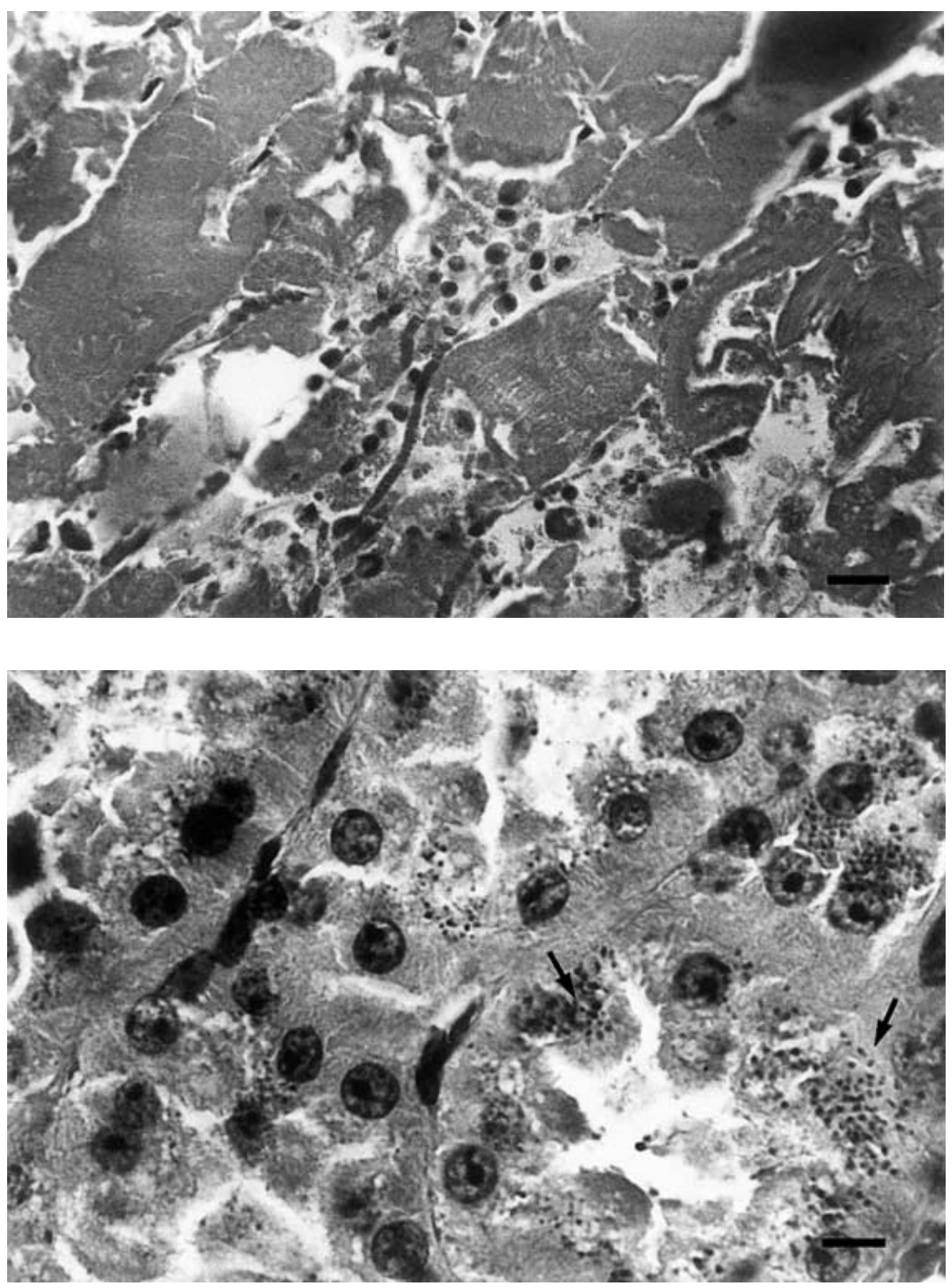

Fig. 3. Photomicrograph of a muscle specimen, showing hyalinization and fragmentation of muscular fibres. Note the inflammatory infiltrate. Haematoxylin and eosin. $\operatorname{Bar}=72 \mu \mathrm{m}$
Fig. 4. Photomicrograph of a kidney specimen, showing proximal tubular cells containing an intracytoplasmic pigment (probably myoglobin, see arrows) and necrosis of tubular cells. Haematoxylin and eosin. $\operatorname{Bar}=29 \mu \mathrm{m}$
$>13 \times 10^{12} / 1$, haemoglobin $>200 \mathrm{~g} / \mathrm{l}$; packed cell volume $>55 \%$ ), leucopenia $\left(<2.5 \times 10^{9}\right.$ leucocytes/l) and neutropenia $\left(<1.0 \times 10^{9}\right.$ neutrophils $\left./ \mu \mathrm{l}\right)$ as negative prognosis indicators in roe deer at 3-4 h post-capture. In this case, all three animals had a heart rate below 200 beats/min at 25 min post-capture and their rectal temperature never reached $41{ }^{\circ} \mathrm{C}$. Neither haematological values nor serum glucose at capture and after transport were indicative of a negative evolution of the animals.

The differences in heart rate presented in Fig. 1 could be due to the chronic parasitic interstitial pneumonia and pneumothorax that animal no. 1 was suffering from, which could increase its mean heart rate and delay the return to heart rate basal values. Alternatively, it could also reflect the interindividual differences existing in heart rate (Hopster, 1998). Raised heart rates after capture are due to physical activity and the acute stress response (Broom and Johnson, 1993). The decline in deer heart rates during the course of the journey may simply reflect their ability to adapt to the movement of the vehicle over time (Waas et al., 1997).

Kock et al. (1987) reported that temperature in bighorn sheep (Ovis canadensis) classified as being 'normal' $\left(40.5^{\circ} \mathrm{C}\right)$ after capture was significantly lower than that of bighorn sheep that died of capture myopathy $\left(41.9^{\circ} \mathrm{C}\right)$. In our study, all animals were below $40.5^{\circ} \mathrm{C}$ for the entire period of monitoring, except for 5 min during which animals 1 and 2 were between 40.5 and $40.6^{\circ} \mathrm{C}$.

Increases in serum creatine kinase (CK), aspartate aminotransferase (AST) and lactate dehydrogenase (LDH) are usually due to an increase in muscular cell permeability and muscular damage resulting from physical stress (Duncan and Prasse, 1986). Some authors think that alanine aminotransferase (ALT) measurement could be useful in cases of capture myopathy (Vassart et al., 1992). Reference values of these parameters have not been found for roe deer, but in comparison with those obtained from other roe deer that 
were also submitted to physical capture and road transport (unpublished data), no differences were found. However, the elevation of serum $\mathrm{CK}$ activity indicated that muscular damage had occurred during capture and transportation.

Increased serum urea and creatinine values were probably caused by prolonged exertion resulting from drive-trapping. Severe, prolonged exercise in man causes an increase in serum urea and creatinine of about $60 \%$ (Finco, 1997). Sealander et al. (1975) also found increased serum urea values in deer physically restrained. If the cause of the elevation had been renal, urea and creatinine levels would have increased instead of decreasing in the 'after transport' sample. McAllum (1985) found that blood urea levels increased in myopathic red deer (Cervus elaphus). High serum lactate concentrations at capture were probably due to the previous intense physical exercise (Kaneko, 1997) and to the activation of the sympathetic-adrenomedullar system (Verde and Gascón, 1987). When anaerobic metabolism changes to aerobic, the lactate concentration decreases, as occurred in the 'after transport' blood sample.

Vigorous short-term exercise at high intensity and muscle necrosis result in hyperkalaemia (Carlson, 1997). In this case, the increases in potassium concentration were also caused by exertion, as it tended to decrease when the animals were at rest, probably because of aldosterone control. McAllum (1985) recorded a potassium level of nearly four times normal in myopathic red deer in the first $30 \mathrm{~min}$ after capture. This was not the case comparing the present data with those of Jaouen (1981).

The use of blood cortisol level as an indicator of stress has been controversial, although some investigators feel that it is potentially the best single indicator of stress in different wildlife species (Franzmann et al., 1975; Spraker, 1982; Morton et al., 1995). However, Kock et al. (1987) did not find any statistical difference in cortisol concentrations between normal bighorn sheep and those that suffered from capture myopathy. No serum cortisol concentrations in roe deer have been reported in the literature for comparison with our results.

Gross and histopathological findings were indicative of acute myopathy and myoglobinaemic nephrosis. These could be related to an ataxic myoglobinuric syndrome resulting from capture and transport operations. The lack of clinical signs and negative prognosis indicators in the period between capture and just before death, the absence of gross muscular lesions in the animal that died 8 days post-capture, the simultaneous deaths of animals captured at different times and the evidence of deliberate human disturbance in the enclosure suggest that death was triggered by a second stress episode. Unlike the delayed peracute syndrome, these animals did not die within several minutes of the second stress episode and this is why it seems improbable that they shared the same pathogenesis. These are the main reasons for using the term 'delayed acute capture myopathy syndrome'. Although it is not found in the literature, it is appropriate for describing the clinical syndrome observed.

\section{Acknowledgements}

This work is part of a research project on 'Capture and handling stress in roe deer' (AGF97-0493) financed by the Comisión Interministerial de Ciencia y Tecnología (CICYT). The authors thank the rangers of the National Game Reserve of Alt Pallars Aran and Cadí-Moixeró for helping with the capture of the animals and the DGR (Direcció General de Recerca) of the Catalan Government for funding the research project.

\section{References}

Broom, D. M., and K. G. Johnson, 1993: Assessing welfare: short-term responses. In: Broom, D. M., and K. G. Johnson (eds), Stress and Animal Welfare, pp. 87-144. Chapman \& Hall, London.

Carlson, G. P., 1997: Fluid, electrolyte, and acid-base balance. In: Kaneko, J. J., J. W. Harvey, and M. L. Bruss (eds), Clinical Biochemistry of Domestic Animals, 5th edn, pp. 485-516. Academic Press, San Diego.

Chalmers, G. A., and M. W. Barrett, 1982: Capture myopathy. In: Hoff, G. L., and J. W. Davis (eds), Noninfectious Diseases of Wildlife, pp. 84-94. Iowa State University Press, Ames.

Duncan, J. R., and K. W. Prasse, 1986: Veterinary Laboratory Medicine, 2nd edn, pp. 175-180. Iowa State University Press, Ames. Fairlie, G., 1964: Myopathy in a roebuck. Vet. Rec. 76, 1147-1148.

Finco, D. R., 1997: Kidney function. In: Kaneko, J. J., J. W. Harvey, and M. L. Bruss (eds), Clinical Biochemistry of Domestic Animals, 5th edn, pp. 441-484. Academic Press, San Diego.

Franzmann, A. W., A. Flynn, and P. D. Arneson, 1975: Serum corticoid levels relative to handling stress in Alaskan moose. Can. J. Zool. 53, 1424-1426.

Harthoorn, A. M., 1976: Physiology of Capture Myopathy. Quinquennial Report. Transvaal Nature Conservation Division, Pretoria. Hopster, H., 1998: Coping strategies in dairy cows. Doctoral Thesis, Agricultural University Wageningen.

Jaouen, M., 1981: Étude hematologique et biochimique d'une population de chevreuils (Capreolus capreolus). Doctoral Thesis, Ecole Nationale Veterinaire d'Alfort.

Kaneko, J. J., 1997: Carbohydrate metabolism and its diseases. In: Kaneko, J. J., J. W. Harvey, and M. L. Bruss (eds), Clinical Biochemistry of Domestic Animals, 5th edn, pp. 45-81. Academic Press, San Diego.

Kock, M. D., R. K. Clark, C. E. Franti, D. A. Jessup, and J. D. Wehausen, 1987: Effects of capture on biological parameters in freeranging bighorn sheep (Ovis canadensis): evaluation of normal, stressed and mortality outcomes and documentation of postcapture survival. J. Wildl. Dis. 23, 652-662.

McAllum, H. J. F., 1985: Stress and postcapture myopathy in red deer. Biol. Deer Prod. 22, 65-72.

Meneguz, P. G., I. Marco-Sanchez, L. Rossi, D. De Meneghi, and M. C. Isaia, 1996: Misurazione dello stress negli ungulati selvatici: esperienze su caprioli (Capreolus capreolus) catturati con rete verticale. Rich. Biol. Selvaggina 24, 447-456.

Morton, D. J., E. Anderson, C. M. Foggin, M. D. Kock, and E. P. Tiran, 1995: Plasma cortisol as an indicator of stress due to capture and translocation in wildlife species. Vet. Rec. 136, 60-63.

Nielsen, L., 1999: Postcapture management. In: Nielsen, L. (ed.), Chemical Immobilization of Wild and Exotic Animals, 1st edn, pp. 161-187. Iowa State University Press, Ames.

Schober, F., and J. Wagner, 1993: Modifcations de la frequence cardiaque apres immobilisation et injection ulterieure d'antidotes chez le chevreuil: utilisation de la biotelemetrie. In: Dubray, D. (ed.), Actes du Symposium sur les Techniques de Capture et de Marquage des Ongulès Sauvages, Mèze, Hérault, 20-22 March 1990, pp. 213216. FDC de l'Hérault, Montpellier.

Sealander, J. A., P. S. Gipson, M. E. Cartwright, and J. M. Pledger, 1975: Behavioral and Physiological Studies of Relationships Between White-tailed Deer and Dogs in Arkansas. Final Report to Arkansas Game and Fish Commission. Department of Zoology, University of Arkansas, Fayetteville.

Shepherd, N. C., 1984: Capture myopathy. In: Proceedings No. 72 of the Deer Refresher Course, 10-14 December 1984, The University of Sydney, Sydney, pp. 487-502. 
Spraker, T. R., 1982: An overview of the pathophysiology of capture myopathy and related conditions that occur at the time of capture of wild animals. In: Nielsen, L., J. C. Haigh, and M. E. Fowler (eds), Chemical Immobilization of North American Wildlife, pp. 83-118. Wisconsin Humane Society, Milwaukee.

Spraker, T. R., 1993: Stress and capture myopathy in artiodactyls. In: Fowler, M. E. (ed.), Zoo and Wild Animal Medicine. Current Therapy, 3, pp. 481-488. W.B. Saunders, Philadelphia.
Vassart, M., A. Greth, S. Anagariyah, and F. Mollet, 1992: Biochemical parameters following capture myopathy in one Arabian Oryx (Oryx leucoryx). J. Vet. Med. Sci. 54, 1233-1235.

Verde, M. T., and M. Gascón, 1987: Mecanismo de estrés en animales domésticos. Vet. Med. 4, 455-464.

Waas, J. R., J. R. Ingram, and L. R. Matthews, 1997: Physiological responses of red deer (Cervus elaphus) to conditions experienced during road transport. Physiol. Behav. 61, 931-938. 